\title{
Propolis: chemical composition, biological properties and therapeutic activity
}

\author{
MC Marcucci \\ Biological Chemistry Laboratory, Chemical Institute of Universidade Estadual de Campinas, \\ CP 6154, cep 13081-970, Campinas, SP, Brazil
}

(Received 23 June 1994; accepted 30 November 1994)

\begin{abstract}
Summary - The plant sources and chemical composition of propolis are reviewed. The chemical constituents that may be relevant to its biological and therapeutic activity are discussed. The cytotoxic activity and antimicrobial and pharmacological properties of propolis are presented. Propolis components, which cause allergy and are responsible for anticancer activity, eg, caffeic acid derivatives, are reported. The therapeutic efficacy of propolis in treating diseases caused by microorganisms is described. Some recent concepts about propolis and its use in medicine are presented.
\end{abstract}

propolis / phenolics / antimicrobial activity / toxicity / therapeutical activity

\section{INTRODUCTION}

In recent years there has been renewed interest in the composition of propolis, a substance that can be regarded as a potential natural source in folk medicine and in the chemical industry. This article describes the composition, biological and pharmacological properties, therapeutic activity and uses of propolis in pharmaceutical and cosmetic products.

\section{COMPOSITION OF PROPOLIS}

Propolis is a natural resinous substance collected by bees from parts of plants, buds and exudates (Ghisalberti, 1979). Bees use it as a sealer for their hives (Garcia-Viguera et al, 1992) and, more importantly, to prevent the decomposition of creatures which have been killed by bees after an invasion of the hive (Brumfitt et al, 1990). Characteristically, it is a lipophilic material, hard and brittle when cold but soft, pliable, and very sticky when warm, hence the name beeglue (Hausen et al, 1987a). It possesses a pleasant aromatic smell, and varys in color, depending on its source and age (Brown, 1989). Among the types of chemical substances found in propolis are waxes, resins, balsams, aromatic and ethereal oils, pollen and other organic matter (Ghisalberti et al, 1978). The proportion of these types of substances varies and depends on the place 
and time of collection (Ghisalberti et al, 1978; Bankova et al, 1992b). The compounds identified in propolis resin originate from 3 sources: plant exudate collected by bees; secreted substances from bee metabolism; and materials which are introduced during propolis elaboration (Ghisalberti, 1979; Marcucci et al, 1994b).

Simple fractionation of propolis to obtain compounds is difficult due to its complex composition. The usual manner was to extract the fraction soluble in alcohol, called 'propolis balsam', leaving the alcoholinsoluble or wax fraction (Ghisalberti, 1979). Although ethanol extract of propolis (EEP) is the most common, extracts with other solvents have been carried out (Villanueva et al, 1964; Cizmárik and Matel, 1970; Hladón et al, 1980; Bankova et al, 1983, 1988, 1989; Manolova et al, 1985; Cortani, 1987, 1991; Grunberger et al, 1988; Andrich et al, 1987; Neychev et al, 1988; Ross, 1990) for identification of many constituents. Many analytical methods have been used for separation and identification of propolis constituents (Bankova et al 1982, 1988, 1989, 1992a, 1994; König, 1986; Cortani, 1987; Pápay et al, 1987; Grenaway et al, 1988, 1989, 1991; Walker and Crane, 1987; Nagy et al, 1989a, 1989b; Campos et al, 1990; Christov and Bankova, 1992; TomásBarberán et al, 1993). The known components of propolis resin are listed in table I.

Vitamins $B_{1}, B_{2}, B_{6}, C, E$, and mineral elements silver, cesium, mercury, lanthanum, antimony, copper, manganese, iron, calcium, aluminium, vanadium and silicon have all been identified in propolis samples (Deblock-Bostyn, 1982; Debuyser, 1983).

The plant origin of propolis has been studied by many researchers. Bankova et al (1992b) showed that propolis composition is very similar to bud exudates. Qualitative composition of many compounds, eg, flavonoids aglycones in propolis of different tree species has indicated that propolis has been collected from Populus fremontii (USA), $P \times$ euramericana (UK), Dalechampia spp and Clusia spp (Equator) (Greenaway et al, 1990); $P$ nigra, $P$ italica, $P$ tremula (Bulgaria) and $P$ suaveolens (Mongolia) (Bankova et al, 1992b; 1994); Betula, Populus, Pinus, Prunus, Acacia, Aesculus hypocastane (Hungary) (Nagy et al, 1985), Clusia minor (Venezuela) (TomásBarberán et al, 1993), Plumeria acuminata and $P$ acutifolia (Hawaiian Islands) (König, 1985) and Betula and Alnus (Polish regions) (Warakomska and Maciejewicz, 1992).

\section{BIOLOGICAL AND PHARMACOLOGICAL PROPERTIES}

\section{Antibacterial activity}

The in vitro activity of propolis against several bacterial strains has been reported (Ghisalberti, 1979; Vanhaelen and Vanhaelen, 1979b; Pepeljnjak et al, 1981, 1982; Pápay et al, 1985b; Kawai and Konishi, 1987; Toth and Papay, 1987; Okonenko, 1988; Petri et al, 1988; Rosenthal et al, 1989; Brumfitt et al, 1990; Cuéllar et al, 1990; Soboleva et al, 1990; Dimov et al, 1991; Dobrowolski et al, 1991; Kujumgiev et al, 1993; Ventura Coll et al, 1993; Langoni et al, 1994; Woisky et al, 1994).

Meresta and Meresta (1985) examined the sensitivity of 75 bacterial strains to propolis extracts. Of these, 69 were identified as Staphylococcus spp and Streptococcus spp. All strains exhibited a high sensitivity to propolis extracts. The antibacterial activity of propolis against $S$ aureus 209P had minimum inhibitory concentration (MIC) and minimum bactericidal concentration (MBC) values of 10 and $120 \mathrm{mg} / \mathrm{ml}$, respectively (Meresta and Meresta, 1980). Valdez Gonzalez et al (1985) observed that EEP inhibited the growth of various bacteria including strains of Streptococcus and Baci- 
lus. Grange and Davey (1990) related that preparations of EEP $(3 \mathrm{mg} / \mathrm{ml})$ completely inhibited the growth of Pseudomonas aeruginosa and Escherichia coli, but had no effect on Klebsiella pneumoniae. Fuentes and Hernandez (1990) showed that EEP had a pronounced activity against Gram-positive bacteria, including $S$ aureus, $E$ coli, $P$ aeruginosa, $B$ subtilis, $S$ epidermidis and Streptococcus sp (B hemolytic). The results of Fuentes and Hernandez were confirmed by Marcucci et al (1994c) with the same $E$ coli strain.

Besides aerobic bacteria, the antimicrobial effects of EEP have been tested against a total number of 267 anaerobic strains. The cultures of bacteria generally showed the highest sensitivity to $1 \mathrm{mg} / \mathrm{ml}$ of EEP (Kedzia, 1986, 1990).

Extracts of propolis have been shown to potentiate the effect of certain antibiotics (Ghisalberti, 1979; Kedzia and Holderna, 1986; Hernandez and Bernal, 1990; Krol et al, 1993). The antibiotic action against $S$ aureus (various strains) and $E$ coli was increased by the addition of propolis to nutrient medium. The presence of propolis prevented or reduced any gradual build-up in tolerance of Staphylococci to antibiotics (Ibragimova and Pankratova, 1983; Meresta and Meresta, 1985).

The antibacterial activity of propolis is reportedly due to flavonoids and aromatic acids and esters present in resin (Debuyser, 1983; Meresta and Meresta, 1985/1986). Galangin, pinocembrin and pinostrobin have been recognized as the most effective flavonoid agents against bacteria (Dimov et al, 1992). Ferulic and caffeic acid also contributes to bactericidal action of propolis (Debuyser, 1983).

Kedzia et al (1990) reported that the mechanism of antimicrobial activity is complicated and could be attributed to a synergism between flavonoids, hydroxyacids and sesquiterpenes. Scheller et al (1977b) and Krol et al (1993) also observed this effect.

\section{Antiviral activity}

There are few data from studies of the antiviral effects of propolis (Esanu et al, 1981; König, 1986; Bankova et al, 1988; Neychev et al, 1988; Debiaggi et al, 1990; Vachy et al, 1990; Amoros et al 1994; Serkedjieva et al, 1992). In virological studies carried out with extracts obtained with various solvents, some fractions affected the reproduction of influenza viruses $A$ and $B$, vaccinia virus and Newcastle disease virus in different biological testing systems (Maksimova-Todorova et al, 1985; Manolova et al, 1985). The action of these active fractions was similar both in strain spectrum and in the degree of antiinfluenza activity of propolis concentrations from $0.2-3.0 \mathrm{mg} / \mathrm{ml}$.

Amoros et al (1992a, 1992b) investigated the in vitro effect of propolis on several DNA and RNA viruses, including herpes simplex type 1, an acyclovir resistant mutant, herpes simplex type 2, adenovirus type 2 , vesicular stomatitis virus and poliovirus type 2. The inhibition of poliovirus propagation was clearly observed. At a concentration of $30 \mu \mathrm{g} / \mathrm{ml}$, propolis reduced the titer of herpes simplex virus by 1000 , whereas vesicular stomatitis and adenovirus were less susceptible. In addition to its effect on virus multiplication, propolis was found to exert a viricidal action on the enveloped viruses herpes simplex (HSV) and vesicular stomatitis virus (VSV).

Flavonoids and aromatic acid derivatives exhibit antiviral activity (Helbig and Thiel, 1982; Ishitsuka et al, 1982; Mucsi, 1984; Mucsi and Pragai, 1985; Kaul et al, 1985; Tsuchiya et al, 1985; Vanden Berghe et al, 1986; Vrijien et al, 1988; Wleklik et al, 1988; Serkedjieva et al, 1992; Amoros et al, 1994). König and Dustmann (1985) verified that luteolin was more active than quercetin, but remarkably less than caffeic acid, in the inhibition of Amazon parrot herpes virus (strain KS144/70) at range concentration of $12.5-200.0 \mathrm{mg} / \mathrm{ml}$. Phenolics 
Table I. Compounds identified in propolis resin.

Basic structure

Alcohols

Aldehydes

Aliphatic acids

and aliphatic esters

Amino acids

Aromatic acids

Aromatic esters

Chalcones and dihydrochalcones

\section{Compound*}

Benzene methanolrt; cinnamyl alcoholrt; glycerolw; $\alpha$-glycero phosphatert; hydroquinonert; isobutenolt; phenethyl alcoholrt; prenyl alcoholt

Benzaldehydet; caproic aldehydet; $p$-hydroxybenzaldehyde ${ }^{t}$; isovanillinghit; protocatechualdehydert; vanillinghirt

Acetic acidt; angelic acidt; butyric acidt; crotonic acidt; fumaric acidt; isobutyric acidt; methylbutyric acidt; isobutyl acetatet; isopentyl acetatet; isopentenyl acetatet

Alanine ${ }^{o p z} ; \beta$-alanine ${ }^{o} ; \alpha$-amino butyric acido; $\delta$-amino butyric acido; arginineopz; asparaginep; aspartic acidopz; cystineop; cysteinz; glutamic acidopz; glycine opz; histidine ${ }^{o p z}$; hydroxyproline ${ }^{o}$; isoleucineopz; leucine ${ }^{o p z}$; lysine ${ }^{o p z}$; methionine ${ }^{o p z}$; ornithine ${ }^{0}$; phenylalanine ${ }^{o p z}$; proline opz; pyroglutamic acidot; sarcosine ${ }^{\circ}$; serine ${ }^{o z}$; threonine ${ }^{o p z}$; tryptophan ${ }^{\circ p}$; tyrosine ${ }^{o p z}$; valineopz

p-Anisic acidirt; benzoic acidghilrtvwx; caffeic acidcghirtv; cinnamicghirt; coumaric $(-0,-m,-p)$ acidghirtv; 3,4-dimethoxycinnamic acidrtvwx; ferulic aciddghilrtww; gallic acidghil; gentisic acidghi; hydroxycinnamic acidt; $p$ hydroxy benzoic acidghilrt; isoferulic acidghiqrwx; 4-methoxy cinnamic acidrtv; protocatechuic acidghilt; salicylic acidghi; vanillic acid rwx; veratric acidrt

Benzyl acetate; benzyl benzoatert; benzyl caffeatertwx; benzyl coumaratelrt; benzyl-3,4-dimethoxycinnamatert; benzyl ferulatertv; benzyl isoferulatert; benzyl salicylatert; butenyl caffeatertv; butyl caffeate ; cinnamyl benzoate ; cinnamyl caffeatertv; butyl caffeatertwx; cinnamyl coumaratert; cinnamyl isoferulatert; ethyl benzoate; ethyl caffeatev $^{\mathrm{r}}$; methyl benzoate $\mathrm{t}$; 2-methyl-2-butenyl caffeatert; 3-methyl-2butenylcaffeatewx; 3-methyl-3-butenyl caffeatetwwx; 3-methyl-3-butenyl coumarate ; 3-methyl-2-butenylferulate ${ }^{t v w x} ; 3$-methyl-3-butenyl ferulatetwx; 2-methyl-2-butenyl isoferulatetwx; 3-methyl-3butenylisoferulate $^{t w x}$; methyl salicylate ${ }^{t w x}$; phenyl ethyl caffeate ${ }^{t w x}$; phenyl ethylcoumaratertwx; phenylethylisoferulatertwx; pentyl caffeate ${ }^{v}$; pentenyl caffeatertv; pentenyl ferulatev; prenylcaffeatet; prenyl coumaratet; prenyl ferulate ${ }^{t}$; prenyl isoferulatel

Alpinetin chalconetw; naringenin chalconet; pinobanksin chalconertw pinobanksin-3-acetate chalconert; pinocembrin chalconertw; pinostrobin chalcone rtvw; sakuranetin chalconet; 2', 6', a-trihydroxy-4'-methoxy chalconert; 2',6'-dihydroxy-4'-methoxydihydro chalcone'w; 2', 4', 6'trihydroxydihydro chalcone ${ }^{t w}$ 
Basic structure

Flavanones

Flavones and flavonols

Hydrocarbons esters ethers, hydroxy and keto waxes

Waxy acids

Ketones

Terpenoids

and other compounds

Steroids

Sugars

\section{Compound *}

Naringenint; pinobanksin ${ }^{\mathrm{Intw}}$; pinobanksin-3-acetatemntw; pinobanksin-3butyratet; pinobanksin-3-hexanoatet ; pinobanksin-3-methyl ethertw; pinobanksin-3-pentanoate ${ }^{t w}$; pinobanksin-3-pentenoate ${ }^{t}$; pinobanksin3-propanoate ${ }^{t w}$; pinocembrinbgklrtvw; pinostrobinfgltvw; sakuranetin fgltw; 3,7-dihydroxy-5-methoxyflavanonev; 2,5 -dihydroxy-7-methoxyflavanone ${ }^{v}$

Acacetinghiklm; apigeninghiklmt; apigenin-7-methyl ethert; chrysinghik!m fisetint; galanginaghiklmrtw; galangin-3-methyl ethermrtw; izalpiningmnrw; isorhamnetingklmn; kaempferideghilnt; kaemplerolghiklmnt; kaempferol-3methyl ethert; kaempferol-7-methyl ethert; kaempferol-7,4'-dimethyl ethert; pectolinarigeninglm; quercetinghiklt; quercetin-3,7-dimethyl ether ${ }^{n t}$; ramnetingkimt ramnocitrin ${ }^{\mathrm{m}}$ tectocrisinghiklnrt

Heneicosanerswy ; hentriacontanerswy; heptacosanerswy; hexacosanew nonacosanerswy; pentacosanerswy; tricosanerswy; tripentacontane $y$; tritriacontane rswy; dotriacontylhexadecanoate ${ }^{u}$; dotriacontyl-[(Z)octadec-9-enoate] ${ }^{\text {; }}$, hexacosylhexadecanoate ${ }^{\text {; }}$ hexacosyl-[( $Z$ octadec-9-enoate] ; octacosylhexadecanoate; octacosyl-[(Z)-octadec9-enoate]utetracosyl-hexadecanoateu; tetracosyl-[(Z)-octadec-9enoate $]^{u}$; tetratriacontyl-hexadecanoate tetratriacontyl-[(Z)-octadec-9enoate $]^{u}$; triacontyl-hexadecanoateu; triacontyl-[(Z)-octadec-9-enoate $]^{u}$

Arachid acidu; behenic acidru; cerotic acidru; lauric acidu; linoleic acidr lignoceric acidruw; montanic acidrw; myristic acidruv; oleic acidru; palmitic acids ruv; stearic acidruv

Acetophenonertv; $p$-acetophenolacetophenonert; dihydroxyacetophenonev; methylacetophenonev; hept-5-en-2-onet; 6methylketonet

$\alpha$-Acetoxibetulenoleht; $\beta$-bisabololehl; 1,8-cineolert; $\alpha$-copaenert; cymenert;

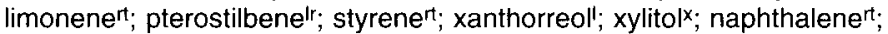
4-hexanolactonert; sesquiterpene alcoholrtw; sesquiterpene alcoholrtw; sesquiterpene diolitw

Calinasterol acetatei; $\beta$-dihydrofucosterol acetatei; ucosterol acetatej stigmasterol acetatej

Fructofuranose-1rwx; fructofuranose-2rwx; $\alpha$-D-glucopyranosewx; $\beta$-Dglucopyranosewx

\footnotetext{
* Common name. a Villanueva et al, 1964; b Villanueva et al, 1970; c Cizmárik and Matel, 1970; d Cizmárik and Matel, 1973; e Ghisalberti , 1979; ' Ghisalberti et al, $1978 \mathrm{~g}$ Vanhaelen and Vanhaelen, 1979a; $\mathrm{h}$ Vanhaelen and Vanhaelen, 1979b; ' Vanhaelen and Vanhaelen, 1980; i Maciejewicz et al, 1982; k Bankova et al, 1983; ' Debuyser, 1983; m Nagy et al, 1985 ; n Pápay et al, 1985a; ${ }^{\circ}$ Gabrys et al, 1986; p Moreira, 1986; q Bankova et al, 1987; ' Greenaway et al, 1987; s Seifert and Hasslinger, 1989; t Greenaway et al, 1990; "Seifert and Hasslinger, 1991; " Bankova et al, 1992b; " García-Viguera et al, 1992; × García-Viguera et al, 1993; y Marcucci et al, 1993; 2 Marcucci et al, 1994a.
} 
such as caffeic acid were found to have a weak activity against influenza although vaccinia and adenovirus were more sensitive than polio and parainfluenza virus (Vanden Berge et al, 1986). Debiaggi et al (1990) studied the effect of propolis flavonoids on the infectivity and replication of some herpes virus, adenovirus, coronavirus and rotavirus strains. The cytotoxicity of flavonoids, including chrysine, kaempferol, acacetin, galangin and quercetin was evaluated.

The antiviral activity of constituents of propolis, such as esters of substituted cinnamic acids, have been studied in vitro. One of them, isopentyl ferulate, significantly inhibited the infectious activity of influenza virus A (Hong Kong strain) at $50 \mathrm{mg} / \mathrm{ml}$ (Serkedjieva et al, 1992). Similar results were found by Amoros et al (1994) when the in vitro activity of 3-methylbut-2-enyl caffeate identified in propolis samples was tested against herpes simplex virus type 1 (HSV-1). The same synthetic compound showed strong inhibition of HSV-1 growth at a concentration of $25 \mathrm{mg} / \mathrm{ml}$. Some authors suggested that the antiviral activity of propolis is due to both the main constituents and the minor components like 3-methylbut-2-enyl caffeate and 3-methylbutyl ferulate (Bankova et al, 1987; Amoros et al, 1994).

\section{Antifungal activity}

Millet-Clerc et al (1987) reported that propolis exhibited an important antifungal activity against Trichophyton and Mycrosporum in the presence of propylene glycol, which interacts synergistically at a $5 \%$ concentration. Combinations of some antimycotic drugs with propolis $(10 \%)$ increased their activity on Candida albicans yeasts. The greatest synergistic effect against most strains was obtained when propolis was added to antifungal drugs (Holderna and Kedzia, 1987). Valdés et al (1987) tested 30 propolis samples produced in Cuba against 2 strains of $C$ albicans. Lisa et al (1989) verified the antifungal activity of propolis extracts $(10 \%$ in ethanol) against 17 fungal pathogens. The EEP inhibited Candida and all tested dermatophytes. Fernandes Junior et al (1994) evaluated the antifungal activity of EEP against $C$ albicans, $C$ parapsilosis, $C$ tropicalis and $C$ guitliermondii; $98 \%$ of fungi samples were sensitive to EEP concentrations of less than $5.0 \%$. Lori (1990) observed that in in vitro tests, propolis concentrations of 5 or $10 \%$ prevented growth of Trichophyton verrucosum. The antifungal activity of propolis was observed in some plant fungi in vitro (La Torre et al, 1990).

\section{Cytotoxic activity}

Extracts of propolis have been examined for in vitro cytotoxic activity by different methods of tissue culture in some cell lines. Hladón et al (1980) investigated the cytostatic activity of propolis extracts on human KB (nasopharinx carcinoma) and HeLa (human cervical carcinoma) cell lines. The ethereal propolis fraction (DEEP) exhibited the strongest cytostatic activity. The secondary fractions of ethyl acetate and butanol of DEEP presented a good activity. Intermediate activity was verified in the $\mathrm{CHCl}_{3} / \mathrm{DEEP}$ fraction. The killing action of propolis on HeLa cells was tested by Ban et al (1983). A concentration of $10 \mathrm{mg} / \mathrm{ml}$ caused $50 \%$ inhibition of colony-forming ability. In assessing the killing action of propolis, flavonoids were also tested. HeLa cells were found to be more sensitive to quercetin and rhamnetin, but less sensitive to galangin. Grunberger et al (1988) described caffeic acid phenethyl ester (CAPE) as the compound partially responsible for the cytostatic properties of propolis. The effect of CAPE on human cancer cell lines was tested in breast carcinoma (MCF-7) and melanoma (SK-MEL-28 and 
SK-MEL-170) cell lines in culture. A dose of $10 \mu \mathrm{g} / \mathrm{ml}$ of CAPE completely inhibited the incorporation of $\left[{ }^{3} \mathrm{H}\right]$ thymidine into the DNA of breast carcinoma. More dramatic effects were observed in the melanoma, colon (HT 29) and renal carcinoma cell lines, but the CAPE effect on normal fibroblasts and melanocytes was significantly less. Because the cytostatic action of CAPE is more effective in transformed cells, it is reasonable to assume that it is responsible for the claimed carcinostatic properties of propolis.

The antitumoral activity of caffeic acid derivatives, eg, methyl ferulate, methyl acetyl ferulate, methyl acetyl isoferulate and methyl diacetyl caffeate, was reported by Inayama et al, 1984. The effect of other caffeic acid derivatives has been investigated by König (1988). Ross (1990) reported that the cytotoxic effect of propolis in vitro against Chinese hamster ovary cancer cell lines was due to naphthalene derivatives in propolis. In vitro tests of extracts of Brazilian propolis from $A$ mellifera on human hepatocellular carcinoma, KB and HeLa cell lines showed that the cytotoxic effects were caused by quercetin, caffeic acid and phenyl ester constituents of propolis (Matsuno, 1992). Scheller et al (1989c) reported a cytotoxic activity of propolis in mice bearing Ehrlich carcinoma in vivo.

\section{Antiprotozoan activity}

Scheller et al (1977b) reported antiprotozoan activity of propolis (EEP) in vitro on 3 strains of Trichomonas vaginalis. EEP solutions in vitro presented a lethal activity on strains at a concentration of $150 \mathrm{mg} / \mathrm{ml}$.

The antiprotozoan activity of propolis was verified in experimental animals infected with Eimeria magna, $E$ media and $E$ perforans treated with $3 \%$ EEP and other antiprotozoan drugs. The coccidiostatic effect of propolis was higher than other drugs (Hollands et al, 1988a). Propolis preparations were classified as a good coccidiostat against Chilomonas paramecium (Hollands et al, 1988b). Torres et al (1990) evaluated the effect of EEP on the growth of the protozoan parasite Giardia lamblia in vitro. At an EEP concentration of $11.6 \mathrm{mg} / \mathrm{ml}$ there was a $98 \%$ inhibition effect.

\section{Other properties}

Many other biological and pharmacological properties of propolis have been described by various authors, including regeneration of cartilaginous tissue (Scheller et al, 1977a), bone tissue (Stojko et al, 1978) and dental pulp (Scheller et al, 1978; Magro Filho and Perri de Carvalho, 1990), anaesthetic activity (Paintz and Metzner, 1979), hepatoprotective activity (Giurgea et al, 1985, 1987; Hollands et al, 1991; Tushevskii et al, 1991), increasing the number of plaque-forming cells in the spleen of populations of immunized males (Scheller et al, 1988), immunomodulatory action (Benková et al, 1989; Dimov et al, 1991, 1992), immunogenic properties (Scheller et al, 1989d), liver detoxifying action, choleretic and antiulcer action in vitro (Kedzia et al, 1990), antioxidant activity (Yanishlieva and Marinova, 1986; Krol et al, 1990; Scheller et al, 1990; Dobrowolski et al, 1991; Misic et al, 1991; Olinescu, 1991; Volpert and Elstner, 1993a, 1993b), anticaries in rats (Ikeno et al, 1991), protection agent against gamma irradiation in mice (Scheller et al, 1989b), antileishmaniosis in hamster (Sartori et al, 1994), antitrypanosomal agent (Higashi et al, 1991) and inhibition of dihydrofolate reductase activity (Strehl et al, 1994).

\section{Toxicity}

As propolis use increases, its side-effects are observed more frequently (Wanscher, 
1976; Petersen, 1977; Monti et al, 1983; Ayala et al, 1985; Machácková, 1985; Rudzki et al, 1985; Tosti et al, 1985; Cirasino et al, 1987; Hausen et al, 1987b; Sartoris et al, 1987; Young, 1987; Hay and Greig, 1990). Propolis contains some compounds which cause toxicity. Beekeeper's dermatitis due to propolis is well known and an apparent association between sensitivity to propolis and to poplar resins has been observed (Hausen et al, 1987a, b).

Hausen et al (1987b) described the incidence of nearly 200 cases of allergic contact dermatitis due to propolis. They identified a substance 1,1-dimethylallyl caffeic acid (LB-1) responsible for the allergy. They also described the sensitizing properties of LB1 in guinea pigs provoked by several propolis samples, demonstrating that this compound is the main sensitizer in propolis. The flavonoid tectochrysin was considered a second allergen, although Schmalle et al (1986) stated that tectochrysin was a very weak sensitizer. Hashimoto et al (1988) verified the allergenic properties of phenylethyl and prenyl esters of caffeic acids from propolis.

Observations of propolis used orally suggest that intestinal absorption could play an important role in propolis sensitization. Limiting the extent of oral administration may be useful in preventing propolis allergy (Angelini et al, 1987; Hausen et al, 1987a, 1988; Kleinhans, 1987; Trevisan and Kokelj, 1987; Machácková, 1988).

\section{Therapeutic activity}

Propolis has been used since ancient times in the remedies in folk medicine in many parts of the world (Ghisalberti, 1979). It has a long tradition of medicinal use in many parts of the world. Many European countries are interested in natural products to heal diseases and propolis is an important product used for this purpose. It is found in pharmaceutical and cosmetic products, such as anti-acne lotion, face creams, ointments, lotions and solutions (Debuyser, 1983; Lejeune et al, 1988; Pons and Cueto, 1988, 1989; Goetz, 1990).

\section{Propolis in dermatology}

Bolshakova (1975) treated 110 patients infected with Trichophyton on the hairy zone of the head with $50 \%$ propolis (as an unguent). In 97 patients, it was found to produce excellent results. Other examples of the treatment of dermatological diseases were described when propolis was used as an antiseptic (Bolshakova, 1975; Gafar et al, 1986), antimycotic (Holderna and Kedzia, 1987; Millet-Clerc et al, 1987), bacteriostatic (Soboleva et al, 1990; Dobrowolski et al, 1991; Stark and Glinski, 1993; Ventura Coll et al, 1993), antiviral (Giurcaneanu et al, 1988; Vachy et al, 1990) and fungistatic (Millet-Clerc et al, 1987) agent. Many other propolis applications in dermatology have been described. It has been used for wound healing, tissue regeneration, treatment of burns, neurodermatitis, microbial eczema, contact dermatitis, leg ulcers, psoriasis, morphea, herpes simplex and genitalis, pruritus ani, dermatophytes, trophic ulcers, pulp gangrene and as an astringent (Bolshakova, 1975; Molnar-Toth, 1975; Scheller et al, 1977a, 1978; Ghisalberti, 1979; Korsun, 1983; Gafar et al, 1986; Hausen et al, 1987a; Giurcaneanu et al, 1988; Ponce de Leon and Benitez, 1988; Goetz, 1990; Fierro Morales, 1994).

\section{Propolis in otorhinolaryngologic (ORL) diseases}

Matel et al (1973) described the treatment of 126 subjects suffering of external otitis, chronic mesotympanic otitis and tympan perforation with propolis solutions (5-10\%) which had a positive therapeutic result in 
most cases. Propolis effects in other ORL diseases were reported: acute inflammations of the ear (Kachnii, 1975; Palos et al, 1989), treatment of mesotympanitis (Popnikolov et al, 1973), pharyngitis (Doroshenko, 1975), tuberculosis (Karimova and Rodionova, 1975), chronic bronchitis (Chuhrienko et al, 1989; Scheller et al, 1989a), rhinopharyngolaryngitis (Isakbaev, 1986), pharyngolaryngitis (Lin et al, 1993a) vasomotor catarrh treatment (ZommerUrbanska et al, 1987) and rhinitis (Nuñez et al, 1988/1989).

\section{Propolis in gynecological diseases}

Zawadzki and Scheller (1973) investigated 90 cases of therapeutic activity of $3 \%$ EEP in cases of vagina and uterus cervix inflammation caused by $S$ pyogenes. They observed that more than $50 \%$ of the cases responded well to treatment with EEP. The action of propolis to treat inflammatory and distrophic lesions of the female genital system caused by protozoan and fungi has been studied. Some 137 cases of diffuse inflammations, ulcerations and ex-ulcerations of cervix uteri diseases were investigated by Roman et al (1989). After 20-25 d of associated treatment (allopathic and apitherapeutic) very good results were obtained in 53 cases, good results in 24 , and satisfactory in 28 cases. The results obtained by Roman et al (1989) confirm that propolis potentiates the antiseptic, antifungal and antitrychomonas actions of specific chemical medicines. Stojko and Stojko (1993) also reported the use of propolis preparations for treatment of gynecological disorders.

\section{Propolis in stomatology}

Mirayes et al (1988) described a clinical assay with an extract of propolis that showed its efficacy against giardiasis. Some 138 patients were studied, 48 children and 90 adults, and treated with propolis (in children, concentration of $10 \%$ and adults $20 \%$ ). At these concentrations, $52 \%$ of the children showed a cure. In adults, the propolis effect was the same as tinidazole, an antiprotozoan drug. When the propolis concentration was elevated to $30 \%$, there was a higher efficacy $(60 \%$ cure versus $40 \%$ with tinidazole). Some authors described the use of propolis in the following therapies: acute colitis, chronic colitis, acute gastric ulcers, and acute duodenal ulcers (Gorbatenko, 1971; Makarov 1972; Nikolov et al, 1973; Kabanov et al, 1989).

\section{Propolis in odontology}

Paintz and Metzner (1979) verified the anaesthetic properties of propolis. Scheller et al (1978), Gafar et al (1986), Magro Filho and Perri de Carvalho (1990) and Ding et al (1993) observed regeneration of dental pulp with gangrene in the presence of propolis. The healing effect of propolis was evaluated in periodontitis (Wang et al, 1993), plaque and gingivitis (Neumann et al, 1986) and buccal affections (Draganova et al, 1989). Neumann et al (1986) suggested that a propolis preparation could be a useful subsidiary treatment in oral hygiene.

\section{Other propolis uses in therapy}

The use of propolis has been reported for other diseases (human and veterinary) including osteoarthritis (Lin et al, 1993b), eyes diseases (Popescu et al, 1993), as an antiinflammatory agent (Mihail et al, 1984; Christova, 1985; Busciglio, 1988; Soboleva et al, 1990; Olinescu, 1991; Fierro Morales, 1994), angiology (Gonzalez et al, 1988/1989) and orthopedic treatment (Quesada and Cueto, 1988/1989). The diverse use of propolis in clinical trials shows that its 
therapeutic efficacy lies mainly in diseases caused by microbial contaminations.

\section{DISCUSSION}

Based on the very complex chemical composition of propolis and its pharmacological and therapeutic properties, we conclude that propolis is a very powerful natural product produced by bees. It can be used to treat human and veterinary diseases with great success. Nevertheless, it is evident that propolis cannot be a remedy for all diseases and any who make such claims are guilty of deception and harm the reputation of all hive products (Tóth, 1985). The great problem with propolis, as with some other hive products, is that its composition varies with the flora of a given area, the time of collection and the inclusion of wax contaminants. This further adds to the problem of defining propolis for medicinal use since the product's quality varies so greatly. Although standardization is possible in principle, exact chemical tests have not been applied yet for the purpose of quality control. The problem of quality control is well demonstrated by the propolis products currently marketed in various countries (Tóth, 1985). It is expected that this review will provide some aid to further investigations about propolis, "the purple gold of the beehive" (Asis, 1989).

\section{ACKNOWLEDGMENTS}

The author is grateful to $F$ Yukio Fujiwara for assistance in reviewing the English text and $P$ Cesar Muniz de Lacerda Miranda for computer assistance.

Résumé - Propolis : composition chimique, propriétés biologiques et activité thérapeutique. On fait le point des connaissances sur la composition chimique de la propolis et ses origines végétales probables (tableau I). Les principaux constituants chimiques sont discutés par rapport à leurs activités biologiques et thérapeutiques : activité antibactérienne, antivirale, antifongique et cytotoxique. Certains composés, par exemple les dérivés de l'acide caféique, ont une action allergène et carcinogène. On rapporte les nombreuses études cliniques concernant l'utilisation thérapeutique de la propolis, principalement contre les maladies microbiennes, dans divers domaines (dermatologie, ORL, gynécologie, odontologie). En conclusion, on souligne la nécessité de développer des tests chimiques précis pour standardiser le produit.

propolis / composition chimique / activité antimicrobienne / toxicité / activité thérapeutique

Zusammenfassung - Propolis: chemische Zusammensetzung, biologische Eigenschaften und therapeutische Aktivität. Die chemische Zusammensetzung von Propolis wird beschrieben (Tabelle I). Es wird hauptsächlich auf die in den letzten 14 Jahren identifizierten Komponenten und ihre mögliche pflanzliche Herkunft eingegangen. Die chemischen Bestandteile, die für die biologische und therapeutische Wirksamkeit verantwortlich sind, werden diskutiert. Die antimikrobielle zytotoxische Aktivität und die pharmazeutischen Eigenschaften von Propolis werden vorgestellt. Einige Komponenten von Propolis (zB Kaffeesäurederivate) mit allergogenen und antikarzinogenen Wirkungen werden beschrieben. Zahlreiche klinische Untersuchungen von Propolis werden dargestellt, besonders die Behandlung von durch Mikroorganismen verursachten Krankheiten. Abschließend werden einige neue Konzepte über Propolis und seine Anwendung in der Medizin dargelegt.

Propolis / Phenole / antimikrobielle Aktivität / Toxizität / therapeutische Aktivität 


\section{REFERENCES}

Amoros M, Sauvager F, Girre L, Cormier M (1992a) In vitro antiviral activity of propolis. Apidologie 23, 231240

Amoros M, Simões CMO, Girre L, Sauvager F, Cormier $M(1992 b)$ Synergistic effect of flavones and flavonols against Herpes Simplex virus Type1 in cell culture. Comparison with the antiviral activity of propolis. $J$ Nat Prod 55, 1732-1740

Amoros $M$, Lurton $E$, Boustie J, Girre L, Sauvager $F$, Cormier M (1994) Comparison of the anti-herpes simplex virus activities of propolis and 3-methylbut2-enyl caffeate. J Nat Prod 57, 644-647

Andrich G, Fiorentini R, Consiglieri A (1987) Characteristics of some examples of propolis from the Ligurian coast. Cittá Api 28, 30-31, 34-35, 37-38 (in Italian)

Angelini G, Vena GA, Meneghini CL (1987) Psoriasis and contact allergy to propolis. Contact Dermatitis 17, 251-253

Asis M (1989) Propoleo: el oro purpura de las abejas. Centro de Información y Documentación Agropecuário, Havana, Cuba, $255 \mathrm{pp}$

Ayala F, Lembo G, Nappa P, Balato N (1985) Contact dermatitis from propolis. Contact Dermatitis 12, 181182

Ban J, Popovic S, Maysinger D (1983) Cytostatic effects of propolis in vitro. Acta Pharm Jugos/ 33, 245-255

Bankova VS, Popov SS, Marekov NL (1982) High performance liquid chromatographic analysis of flavonoids from propolis. J Chromatogr 242, 135143

Bankova VS, Popov SS, Marekov NL (1983) A study on flavonoids of propolis. J Nat Prod 46, 471-474

Bankova V, Dyulgerov A, Popov S, Marekov N (1987) A GC/MS study of the propolis phenolic constituents. Z Naturforsch 42C, 147-151

Bankova V, Popov S, Marekov N et al (1988) On the chemical composition of some propolis fractions with antiviral action. Acta Microbiol Bulg 23, 52-57 (in Bulgarian)

Bankova VS, Popov SS, Marekov NL (1989) Isopentenil cinnamates from poplar buds and propolis. Phytochemistry 28, 871-873

Bankova V, Christov R, Stoev G, Popov S (1992a) Determination of phenolics from propolis by capillary gas chromatography. J Chromatogr 607, 150153

Bankova V, Dyulgerov A, Popov S et al (1992b) Propolis produced in Bulgaria and Mongolia: phenolic compounds and plant origin. Apidologie 23, 79-85

Bankova V, Christov R, Popov S, Pureb O, Bocari G (1994) Volatile constituents of propolis. Z Naturforsch $49 \mathrm{C}, 6-10$
Benková M, Borosková Z, Dubaj J, Széchenyi S (1989) The immunomodulative effect of propolis preparations on guinea pigs with experimental ascaridosis. Helminthologia 26, 163-172

Bolshakova VF (1975) Employment of propolis in dermatology. 20th Int Beekeeping Jub Congr, Apimondia, Bucharest, Romania 134-136

Brown R (1989) Hive products: pollen, propolis and royal jelly. Bee World 70, 109-117

Brumfitt W, Hamilton-Miller JTM, Franklin I (1990) Antibiotic activity of natural products: 1 . Propolis. Microbios 62, 19-22

Busciglio JA (1988) Antiinflammatory topical composition containing lidocaine and diphenhydramine [and propolis]. USA Patent 4748 022, 5 pp

Campos MGR, Sabatier S, Amiot MJ, Aubert S (1990) Characterization of flavonoids in three hive products: bee pollen, propolis and honey. Planta Med $56,580-581$

Christov R, Bankova V (1992) Gas chromatographic analysis of underivatized phenolic constituents from propolis using an electron-capture detector. $J$ Chromatogr 623, 182-185

Christova VM (1986) A propolis-enriched wax therapy against inflammatory diseases of the articular-muscular system. Proc 30th Int Apicultural Congress, Nagoya, Japan, Apimondia, Bucharest, Romania, 429-431

Chuhrienko ND, Cherkasova Al, Zahartseva LI, Gladchun VP, Klevanik VA, Kijko IA (1989) Complex treatment of chronic bronchitis with apicultural products. Proc 32nd int Congr Apiculture Rio de Janeiro, Brazil, Apimondia, Bucharest, Romania, 211-212

Cirasino L, Pisati A, Fasani F (1987) Contact dermatitis from propolis. Contact Dermatitis 16, 110-111

Cizmárik J, Matel I (1970) Examination of the chemica composition of propolis. I. Isolation and identification of the 3,4-dihydroxycinnamic acid (caffeic acid) from propolis. Experientia 26, 713

Cizmárik J, Matel I (1973) Examination of the chemical composition of propolis. II. Isolation and identification of 4-hydroxy-3-mehtoxycinnamic acid (ferulic acid) from propolis. J Apic Res 12, 63-65

Cortani G (1987) Procedimento per la preparazione di un estratto di propoli. Apic Mod 78, 147-150

Cortani G (1991) Estrazione della frazione oleoresinosa della propoli ed esempi di utilizzazione di tale resina nella preparazione di prodotti cosmetici. Riv Ital Sostanze Grasse 68, 99-100

Cuéllar AC, Hernández NMR, Pérez JM (1990) Nueva estructura antimicrobiana del propóleo colectado en Cuba. Rev Cubana Farm 24, 51-58

Debiaggi M, Tateo F, Pagani L, Luini M, Romero $E$ (1990) Effects of propolis flavonoids on virus infectivity and replication. Microbiologica 13, 207-213 
Deblock-Bostyn G (1982) L'Abeille et ses produits. Bull Soc Pharm Lille 38, 181-203

Debuyser E (1983) La propolis. Docteur en Pharmacie Thesis, Université de Nantes, France, $82 \mathrm{pp}$

Dimov V, Ivanovska N, Manolova N, Bankova V, Nikolov $N$, Popov S (1991) Immunomodulatory action of propolis. Influence on anti-infectious protection and macrophage function. Apidologie 22, 155-162

Dimov V, Ivanovska N, Bankova V, Nikolov N, Popov $S$ (1992) Immunomodulatory action of propolis: IV. Prophylatic activity against Gram-negative infections and adjuvant effect of water-soluble derivative. Vaccine $10,817-823$

Ding RM, Shi JN, Song SP, Tang JX, Li SY (1993) Observaciones acerca de 300 casos de la pulpa dentaria, mediante um preparado con propóleos. Proc 33rd Int Congr Apiculture Beijing, China, Apimondia, Bucharest, Romania, 135

Dobrowolski JW, Vohora SB, Sharma K, Shah SA, Naqvi SAH, Dandiya PC (1991) Antibacterial, antifungal, antiamoebic, antiinflammatory and antipyretic studies on propolis bee products. $J$ Ethnopharmacol $35,77-82$

Doroshenko PN (1975) Propolis and chronic pharyngitis, In: A Valuable Product of Beekeeping: Propolis. Researches and Views on it Composition, Properties and Therapeutic Value, Apimondia, Bucharest, Romania, 106

Draganova L, Dishovski C, Dishovska Z, Shkendevov $S$, Samnaliev $M(1989)$ In vitro and in vivo studies of drugs on the basis of propolis for local application. Proc 32nd int Congr Apiculture Rio de Janeiro, Brazil, Apimondia, Bucharest, Romania, 221

Esanu V, Prahoveanu E, Crisau I, Cioca A (1981) The effect of aqueous propolis extract of rutin and of rutin-quercetin mixtures on experimental influenza virus infection in mice. Virologie 32, 213-215

Fernandes Junior A, Sugizaki MF, Fogo ML, Lopes CAM, Funari, SRC (1994) In vitro susceptibility of Candida albicans to propolis. Proc N Iberolatinamerican Meeting Apic, Ministerio de Agricultura, Ganadería y Recursos Renovables, Rio Cuarto, Argentina, 209211

Fierro Morales W (1994) Propiedades terapeuticas del propoleos. Proc IV Iberolatinamerican Meeting Apic, Ministerio de Agricultura, Ganadería y Recursos Renovables, Rio Cuarto, Argentina, 1-7 (Addendum)

Fuentes AMO, Hernández NR (1990) Accion antimicrobiana de los extractos alcoholicos de propóleo. Rev Cubana Farm 24, 34-44

Gabrys J, Konecki J, Krol W, Scheller S, Shani J (1986) Free amino acids in bee hive product (propolis) as identified and quantified by gas-liquid chromatography. Pharm Res Commun 18, 513-518

Gafar M, Sacalus A, David E, David N (1986) Treatment of simple pulp gangrene with the apitherapy product "propolis". Stomatologie 33, 115-117 (in Romanian)
Garcia-Viguera C, Greenaway W, Whatley FR (1992) Composition of propolis from two different Spanish regions. Z Naturforsch 47C, 634-637

García-Viguera C, Ferreres F, Tomás-Barberán FA (1993) Study of Canadian propolis by GC-MS and HPLC. Z Naturforsch 48C, 731-735

Ghisalberti EL (1979) Propolis: a review. Bee World 60, 59-84

Ghisalberti EL, Jefferies PR, Lanteri R, Matisons J (1978) Constituents of propolis. Experientia 34, 157-158

Giurcaneanu F, Crisan I, Esanu V, Cioca V, Cajal N (1988) Traitement de l'herpès cutané et du zona zoster à l'aide de Nivcrisol-D. Rev Roum Med Virol $39,21-24$

Giurgea R, Rusu MA, Popescu H, Polinicencu C (1985) Biochemical modifications in carbon tetrachloride intoxications and hepatoprotector effect of standardized propolis extract (SPE) in wistar rats. Clujul Med 58, 272-276 (in Romanian)

Giurgea R, Rusu MA, Popescu H, Polinicencu C (1987) Biochemical effects of standardized propolis extract(SPE) and of silyimarin on the liver of ethy alcohol intoxicated rats. Agressologie 28, 831-832

Goetz $P$ (1990) Monographies médicalisées de phyto thérapie: propolis. Phytotherapie 3, 29-30

Gonzalez A, Varela F, Hurtado O, Cueto DJ (1988/1989) Experiencia en angiologia. Mem I Simp Efecto del Propoleo en la Salud Humana y Animal, Varadero, Cuba, 262-263

Gorbatenko AG (1971) Treatment of ulcer patients with a 30\% alcohol propolis solution. Vrach Delo 3, 22-24 (in Russian)

Grange JM, Davey RW (1990) Antibacterial properties of propolis (bee glue). J R Soc Med 83, 159-160

Greenaway W, Scaysbrook T, Whatley FR (1987) The analysis of bud exudate of Populus $x$ euramericana, and of propolis, by gas chromatography-mass spectrometry. Proc R Soc (Lond) Ser B 232, 249272

Greenaway W, Scaysbrook T, Whatley FR (1988) Compostion of propolis of Oxfordshire, UK and its relation to poplar bud exudate. Z Naturforsch 43C, 301-304

Greenaway W, Scaysbrook T, Whatley FR (1989) Headspace volatiles from propolis. Flavour Fragr $J 4$, 173-175

Greenaway W, Scaysbrook T, Whatley FR (1990) The composition and plant origins of propolis: a report of work at Oxford. Bee World 71, 107-118

Greenaway W, May J, Scaysbrook T, Whatley FR (1991) Identification by gas chromatography-mass spectrometry of 150 compounds in propolis. $Z$ Naturforsch 46C, 111-121

Grunberger D, Banerjee R, Eisinger K et al (1988) Preferential cytotoxicity on tumor cells by caffeic acid phenethyl ester isolated from propolis. Experientia 44, 230-232 
Hashimoto T, Tori M, Asakawa Y, Wollenweber E (1988) Synthesis of two allergenic constituents of propolis and poplar bud excretion. $Z$ Naturforsch $43 C, 470-$ 472

Hausen BM, Wollenweber E, Senff H, Post B (1987a) Propolis allergy. I. Origin, properties, usage and literature review. Contact Dermatitis 17, 163-170

Hausen BM, Wollenweber E, Senff H, Post B (1987b) Propolis allergy. II. The sensitizing properties of 1,1dimethylallyl caffeic acid ester. Contact Dermatitis $17,171-177$

Hausen BM, Wollenweber E (1988) Propolis allergy. III. Sensitization studies with minor constituents. Contact Dermatitis 19, 296-303

Hay KD, Greig DE (1990) Propolis allergy: a cause of oral mucositis with ulceration. Oral Surg Oral Med Oral Pathol 70, 584-586

Helbig A, Thiel KD (1982) Comparison of the antiviral activity of oxidizing caffeic acid and hydrocaffeic acid against Herpesvirus hominis types 1 and 0 in vitro. Pharmazie 37, 603-604

Hernández NMR, Bernal KC (1990) Efecto antibiótico del propóleo frente a cepas de Staphylococcus aureus de origen clínico humano. Rev Cubana Farm 24, 45-50

Higashi KO, Cassilhas AP, Meirelles MNL, Castro SL (1991) Effect of propolis extract on Trypanosoma cruzi-infected cell cultures and experimental animals. Mem Inst Osvaldo Cruz 86, 236

Hladón B, Bylka W, Ellnaim-Wojtaszek M et al (1980) In vitro studies on the cytostatic activity of propolis extracts. Arzneim-Forsch Drug Res 30, 1847-1848

Holderna $E$, Kedzia B (1987) Investigations upon the combined action of propolis and antimycotic drugs on Candida albicans. Herba Pol 33, 145-151

Hollands I, Miyares C, Pimienta R (1988a) Control de la calidad de la propolisina (extracto alcohólico de propóleos) utilizado como coccidiostático mediante un método biológico. Rev Cubana Cienc Vet 19 , 319-326

Hollands I, Miyares C, Sigarroa A (1988b) Análisis comparativo entre la acción del propóleos, la sulfaquinoxalina y la sulfametacina en conejos afectados por coccidiosis. Rev Cubana Cienc Vet 19 , 99-104

Hollands I, Mandado S, Domingues C (1991) Demonstración ultraestrutural del efecto citohepatoprotector del propóleos. Rev Cubana Cienc Vet 22, 85-90

Ibragimova Al, Pankratova NV (1983) Combined antimicrobial effect of propolis and antibiotics on pathogenic Staphylococci. Sb Nauchn Tr Kaz Vet Inst 43-46 (in Russian)

Ikeno K, Ikeno T, Miyazawa C (1991) Effects of propolis on dental caries in rats. Caries Res 25, 347-351

Inayama S, Harimaya $\mathrm{K}$, Hori $\mathrm{H}$ et al (1984) Studies on non-sesquiterpenoid constituents of Gaillardia pul- cholla II. Less lipophilic substances, methylcaffeate as an antitumor catecholic. Chem Pharm Bull 32, 1135-1141

Isakbaev M (1986) Combined treatment of patients with atrophic rhinopharyngolaryngitis. Vest Otorinolaringol 3, 78-79 (in Russian)

Ishitsuka $H$, Ohsawa $C$, Ohiwa T, Umeda I, Suhara $Y$ (1982) Antipicornavirus flavone RO-09-0179. Antimicrob Agents Chemother 22, 611-616

Kabanov AN, Suvorov AM, Lesnykh lu F, Kononov AV, Lopushanski VG (1989) Endoscopic treatment of duodenal ulcers with proposol. Sov Med 6, 92-94

Kachnii GG (1975) Treatment of acute inflammation of the middle ear with propolis. In: $A$ Valuable Product of Beekeeping: Propolis. Research and Views on its Composition, Properties and Therapeutic Value. Apimondia, Bucharest, Romania, 106

Karimova ZL, Rodionova El (1975) Use of propolis for the treatment of pulmonary and bronchial tuberculosis. In: A Valuable Product of Beekeeping: Propolis. Research and Views on its Composition, Properties and Therapeutic Value. Apimondia, Bucharest, Romania, 114-115

Kaul TN, Middleton E, Ogra PL (1985) Antiviral effect of flavonoids on human viruses. J Med Virol 15, 71-79

Kawai $Y$, Konishi $\mathrm{H}$ (1987) Antimicrobial activity of propolis and its application to cosmetics. Fragrance $J 15$ 29-33 (in Japanese)

Kedzia A (1986) Effect of ethanol extract of propolis (EEP) on anaerobic bacteria. Herba Pol 32, 53-58

Kedzia A (1990) Sensitivity of anaerobic bacteria to the ethanol extract of propolis. Phytothérapie 6, 4-6

Kedzia B, Holderna E (1986) Investigations on the combined action of antibiotics and propolis on Staphylococcus aureus. Herba Pol 32, 187-195 (in Polish)

Kedzia B, Geppert B, Iwaszkiewicz J (1990) Pharmacological Investigations of ethanolic extract of propolis. Phytothérapie 6, 7-10

Kleinhans D (1987) Airborne contact dermatitis due to propolis. Contact Dermatitis 17, 187-188

König B (1985) Plant sources of propolis. Bee World 66, 136-139

König B (1986) Studien zur antivirotischen Aktivität von Propolis (Kittharz der Honigbiene, Apis mellifera $\mathrm{L}$ ), Dissertation zur Erlangung des Doktorgrades der Naturwissenschaften, Universität Hannover, Germany, 83 pp

König B (1988) Neues über Propolis: Antitumorwirkung und Allergie durch Kaffeesäurederivative. Heilkunst $101,453-456$

König B, Dustmann JH (1985) The caffeoylics as a new family of natural antiviral compounds. Naturwissenschaften 72, 659-661

Korsun VP (1983) The use of propolis in treating trophic ulcers. Vestn Dermatol Venerol 11, 46-48 (in Russian) 
Krol W, Czuba Z, Scheller S, Gabrys J, Grabiec S, Shani $J$ (1990) Antioxidant property of ethanolic extract of propolis (EEP) as evaluated by inhibiting the chemiluminescence oxidation of luminol. Biochem Int 21 , 593-597

Krol W, Scheller S, Shani J, Pietsz G, Czuba Z (1993) Synergistic effect of ethanolic extract of propolis and antibiotics on the growth of Staphylococcus aureus. Arzneim-Forsch Drug Res 43, 607-609

Kujumgiev A, Bankova, V, Ignatova A, Popov S (1993) Antibacterial activity of propolis, some of its components and their analogs. Pharmazie 48, 785-786

La Torre A, Guccione M, Imbroglini G (1990) Indagine preliminare sull'azione di preparati a base di propoli nei confronti di Botrytis cinerea Pers della fragola. Apicoltura 6, 169-177

Langoni H, Domingues PF, Funari SRC et al (1994) Prototheca zopfii as mastitis in cows agent. Clinical and therapeutical trials. Proc $\mathrm{N}$ Iberolatinamerican Meet ing Apic, Ministerio de Agricultura, Ganadería y Recursos Renovables, Rio Cuarto, Argentina, 219221 (in Portuguese)

Lejeune B, Pourrat A, Dehmouche H (1988) Propolis: utilization en dermocosmétologie. Parf Cosmet Arom 82, 73-77

Lin YL, Ye JY, Chen YX, Zhang JB (1993a) El tratamiento de la faringo-laringitis, mediante emulsión de propóleos, administrada por atomización. Proc XXXIII Int Congr Apiculture Beijing, China, Apimondia, Bucharest, Romania, 138

Lin YL, Ye JY, Luo XR, Zeng XX, Chen YX (1993b) Observaciones acerca de 60 casos de osteoartritis, tratada mediante ionoforesis con propóleos y ácido acético glacial. Proc XXXIII Int Congr Apiculture Beijing, China, Apimondia, Bucharest, Romania, 139

Lisa M, Leifertova I, Baloun J (1989) Fungistatic effect of propolis. Folia Pharm Univ Carol 13, 29-44; Chem Abstr (1991) 114, 225558K

Lori GA (1990) Acción fungicida del propóleos en la dermatomicosis bovina. Ind Apic 1, 38-43

Machacková J (1985) Contact dermatitis to propolis. Contact Dermatitis 13, 43-44

Machacková J (1988) The incidence of allergy to propolis in 605 consecutive patients patch tested in Prague. Contact Dermatitis 18, 210-212

Maciejewicz W, Daniewiski M, Mielniczuk Z, Suprynowicz $Z$ (1982) Gas chromatography-mass spectrometry investigation of propolis. Analysis of $\beta$-steroids. Acta Pol Pharm 39, 277-279

Magro Filho O, Perri de Carvalho AC (1990) Application of propolis to dental sockets and skin wounds. $J$ Nihon Univ Sch Dent 32 4-13

Makarov FD (1972) Propolis treatment of patients with ulcer disease and pyloroduodenitis. Vrach Delo 4, 93-96 (in Russian)
Maksimova-Todorova V, Manolova N, Gegova G et al (1985) Antiviral action of some fractions isolated from propolis. Acta Microbiol Bulg 17, 79-84 (in Bulgarian)

Manolova NH, Maximova VA, Gegova GA et al (1985) On the antiinfluenza action on fractions from propolis. C R Bulg Acad Sci, Biologie (Virol) 38, 735737

Marcucci, MC, Salatino MLF, Salatino A (1993) Propolis constituents: waxes. Proc SIMCRO (Brazilian Symposium of Chromatography), FM Lanças, Águas de São Pedro, Brazil, 37

Marcucci MC, Camargo FA, Lopes CMA (1994a) Identification of some propolis constituents: amino acids. Proc XXIII Annual Meeting Braz Biochem Soc, Caxambú, Brazil, 191

Marcucci MC, Salatino MLF, Salatino A, Lopes CMA (1994b) Chemical and biological studies of Brazilian propolis. Proc IV Iberolatinamerican Meeting Apic, Ministerio de Agricultura, Ganaderia y Recursos Renovables, Rio Cuarto, Argentina, 193-196 (in Portuguese)

Marcucci MC, Gimenez SMN, Moraes SG, Lopes CMA (1994c) Antibacterial activity of propolis extracts. Proc 17th Annual Meeting Braz Chem Soc, Caxambú, Brazil, QB 08

Matsuno T (1992) Isolation and characterization of the tumoricidal substances from Brazilian propolis. Honeybee Sci 13, $49-54$ (in Japanese), Apic Abstr (1993) 44,287

Matel I, Straka J, Cizmárik J (1973) Results of the use of propolis in the treatment of ear, nose and throat diseases. In: Rep 1st Int Symp Propolis (J Cizmárik, ed), Min Pol Vyz SSR Prír, Bratislava, Czechoslovakia, 64-66 (in Slovak)

Meresta L, Meresta T (1980) Effect of pH on bacterial activity of propolis. Bull Vet Inst Pulawy 24, 21-25

Meresta L, Meresta T (1985) An attempt to use propolis extract in the treatment of mastitis of cows. Med Weter 41, 489-492 (in Polish), Apic Abstr (1988) $39(3)$

Meresta L, Meresta T (1985/1986) Antibacterial activity of flavonoid compounds of propolis, occurring in flora in Poland. Bull Vet Inst Pulawy 28-29, 61-63, Apic Abstr (1990) 41, 1345

Mihail N, Giurgea R, Coprean D, Popescu H, Polincencu $C$ (1984) Some data on the anti-inflammatory action of a standardized propolis extract. Rev Roum Biol, Ser Biol Anim 29, 129-131

Millet-Clerc J, Michel D, Simeray J, Chaumont JP (1987) Étude préliminaire des propriétes fongistatiques de la propolis comparées à celles de quelques produits commerciaux. Plant Med Phytother 21, 3-7

Mirayes C, Hollands I, Castaneda C et al (1988) Therapeutic trials with the propolis-based product Propolisina in human giardiasis. Acta Gastroent Latinoam 18, 195-202 
Misic V, Ondrias K, Gergel D, Bullová D, Such y V, Nagy M (1991) Lipid peroxidation of lecithin liposomes depressed by some constituents of propolis, Fitoterapia $62,215-220$

Molnar-Toth M (1965) Therapeutic results of use of propolis in various cutaneous affections. 20th int Beekeeping Jub Congr. Apimondia, Bucharest, Romania, 1-3

Monti M, Berti E, Carminatti G, Cusini M (1983) Occupational and cosmetic dermatitis from propolis. Contact Dermatitis 9, 163

Moreira TF (1986) Chemical composition of propolis: vitamins and amino acids. Rev Bras Farmacogn 1, 12-19 (in Portuguese)

Mucsi 1 (1984) Combined antiviral effect of flavonoids and 5-ethyl-2'-deoxyuridine on the multiplication of herpes virus. Acta Virol 28, 395-400

Mucsi I, Pragai BM (1985) Inhibition of virus multiplication and alteration of cyclic AMP level in cell cultures by flavonoids. Experientia 41, 6-7

Nagy E, Pápay V, Litkei Gy, Dinya Z (1985) Investigation of the chemical constituents, particularly the flavonoids components of propolis and Populi gemma by the GC/MS method. In: Flavonoids and Bioflavonoids (L Farkas, M Gábor, F Kallay, eds), Elsevier, Amsterdam, The Netherlands, 233-240

Nagy $M$, Suchy $V$, Uhrin D, Ubik K, Budesinsky $M$, Grancai D (1989a) Constituents of propolis of Czechoslovak origin. V Chem Pap 42, 691-696

Nágy M, Suchy V, Ubik K, Uhrín D, Grancai D (1989b) Constituents of propolis of Czechoslovak origin. VI. Quercetin derivatives. Cesk Farm 38, 23-25 (in Czechoslovakian), Apic Abstr (1991) 42, 339

Neychev H, Dimov V, Vuleva V et al (1988) Immonomodulatory action of propolis. II. Effect of water-soluble fraction on influenza infection in mice. Acta Microbiol Bulg 23, 58-62

Neumann D, Götze G, Binus W (1986) Klinische studie zur Untersuchung der Plaque-und Gingivitishemmung durch Propolis. Stomatol DDR 36, 677-681, Apic Abstr (1989) 40, 108, Apic Abstr (1989) 40, 1008

Nikolov ST, Todorov V, Guéorguiéva E, Drianovski S, Vassilev V (1973) Experimental and clinical observations on the influence of propolis on patients with acute and chronic colitis. In: Rep 1st int Symp Propolis ( $\mathrm{J}$ Cizmárik, ed), Bratislava, Czechoslovakia, 6063 (in Slovak), Apic Abstr (1977) 28, 1381

Nuñez C, Feijoo G, Hidalgo E, Lopez E, Cueto DJ (1988/1989) Uso del propoleo en otorrinolaringologia. Mem / Simp Efectos del Propóleo en la Salud Humana y Animal, Varadero, Cuba, 269-271

Okonenko LB (1988) Salmonella infections and propolis. Zdravookhr Kaz 1, 55-57 (in Russian), Apic Abstr (1991) 42, 696

Olinescu R (1991) Antioxidant and antiinflammatory action of propolis. Stud Cercet Biochim 34, 19-25 (in Romanian)
Paintz M, Metzner J (1979) Zur lokalanästhetischen Wirkung von Propolis und einigen Inhaltsstoffen. Pharmazie 34, 839-841

Palos E, Popescu F, Mateescu C (1989) Apitherapeutics in the treatment of several otorhinolaryngologic diseases. Proc XXXII Int Congr Apiculture Rio de Janeiro, Brazil, Apimondia, Bucharest, Romania, 214

Pápay V, Tóth L, Soltész N, Nagy É, Litkei G (1985a) Isolated compounds from Hungarian propolis and $P O P$ uli gemma. In: Flavonoids and Biofiavonoids ( $\mathrm{L}$ Farkas, M Gábor, F Kallay, eds), Elsevier, Amsterdam, The Netherlands, 233-240

Pápay V, Tóth L, Soltész M et al (1985b) Pharmacological activities of fractions and isolated compounds of Hungarian propolis and Populi gemma. Proc 30th Int Congr Apiculture Nagoya, Japan, Apimondia, Bucharest, Romania, 465-468

Pápay V, Soltész M, Csizmadia B, Tóth L (1987) Chemical and pharmacological study of propolis from various locations. Acta Pharm Hung 57, 143-151 (in Hungarian)

Pepeljnjak S, Jalsenjak I, Maysinger D (1981) Influence of microencapsulated propolis extract on Bacillus subtilis strain IP-5832. Acta Pharm Jugos/ 31, 2732

Pepeljnjak S, Jalsenjak I, Maysinger D (1982) Growth inhibition of Bacillus subtilis and composition of various propolis extracts. Pharmazie 37, 884-885

Petersen HO (1977) Hypersensitivity to propolis. Contact Dermatitis 3, 278-279

Petri G, Lemberkovics E, Foldvari M (1988) Examination of differences between propolis (bee glue) produced from different floral environments. In: Flavours and Fragrances: a World Perspective (BM Laurenc, BD Mookherjee, BJ Willis, eds), Elsevier, Amsterdam, The Netherlands, 439-446

Ponce de Leon R, Benitez P (1988) Estudio morlológico comparativo del efecto de la propolina, el alcohol y el bálsamo de Shostakoski como agentes cicatrizantes. Investigaciones Cubanas sobre el Propóleos 157-160

Pons O Cueto DJ (1988/1989) Experiencia en dermatologia. Mem I Simp Efectos del Propóleo en la Salud Humana y Animal, Varadero, Cuba, 271-272

Popescu MP, Dana A, Popescu M (1993) El empleo de los productos apícolas en el tratamiento de la opacificación incipiente del cristalino. Beijing, China, Apimondia, Bucharest, Romania, 140

Popnikolov P, Pocinková P, Doncev S (1973) Treatment of chronic purulent mesotympanitis with propolis. In: Rep 1st Int Symp Propolis (J Cizmárik, ed) Bratislava, Czechoslovakia, 45-46 (in Slovak)

Quesada A, Cueto DJ (1988/1989) Investigaciones Cubanas sobre el Propóleo. Mem I Simp Efectos del Propóleo en la Salud Humana y Animal, Varadero, Cuba, 263- 264 
Roman S, Palos E, Mateescu C (1989) Treatment of some gynaecological diseases with apitherapeutical products. Proc XXXII int Congr Apiculture Rio de Janeiro, Brazil, Apimondia, Bucharest, Romania, 215-216

Rosenthal C, Tamarin R, Samish S, Elad D (1989) Demonstration on the inhibitory effect of propolis on microbial strains. Proc XXXIInd Int Congr Apiculture Rio Janeiro, Brazil, Apimondia, Bucharest, Romania, 224

Ross PB (1990) The effects of propolis fractions on cells in tissue culture. MPhil thesis, University of Wales College of Cardiff, UK, $193 p$

Rudzki E, Grzywa Z, Pomorski Z (1985) New data on dermatitis from propolis. Contact Dermatitis $13,43-$ 44

Sartori A, Nagashi AM, Yoshida ELA, Funari SRC, Peraçoli MTS (1994) Antileishmania effect of propolis. Proc IV Iberolatinamerican Meeting Apic, Ministerio de Agricultura, Ganadería y Recursos Renovables, Rio Cuarto, Argentina, 217-218 (in Portuguese)

Sartori S, Filippelli A, Cebrelli G, Santolo GP, Maragnani $P$, Paggio A (1987) Dermatitis due to propolis. Chron Dermatol 18, 867-870

Scheller S, Stojko A, Szwarnowiecka I, Tustanowski J, Obuszko Z (1977a) Biological properties and clinical application of propolis VI. Arzneim-Forsch Drug Res $27,2138-2140$

Scheller S, Szaflarski J, Justanowski J, Nolewajka E, Stojko A (1977b) Biological properties and clinical application of propolis I. Arzneim-Forsch Drug Res $27,889-890$

Scheller S, llewicz L, Luciak M, Skrobidurska D, Stojko A, Matuga W (1978) Biological properties and clinical application of propolis IX. Arzneim-Forsch Drug Res 28, 289-291

Scheller S, Gazda G, Pietz G et al (1988) The ability of ethanolic extract of propolis to stimulate plaque formation in immunized mouse spleen cells. Pharmacol Res Commun 20, 323-328

Scheller S, Aleksandrowicz J, Nikodemowicz E et al (1989a) Trials of immunoregulation in patients with chronic bronchitis. Immunol Pol 14, 304-305 (in Polish); Apic Abs (1991) 42, 1068

Scheller S, Gazda G, Krol W et al (1989b) The ability of ethanol extract of propolis (EEP) to protect mice against gamma irradiation. Z Naturforsch $44 \mathrm{C}, 1049$ 1052

Scheller S, Krol W, Swiacik J, Owczarek S, Gabrys J Shani $J(1989 \mathrm{c})$ Antitumoral property of ethanolic extract of propolis in mice-bearing Ehrlich carcinoma as compared to bleomycin. Z Naturforsch $44 \mathrm{C}, 1063-$ 1065

Scheller S, Owczarek S, Krol W, Malinowska B, Nicodemowicz E, Aleksandrowicz J (1989d) Immunonisierungsversuche bei zwei Fällen von Alveolitis Fibroticans bei abnehmender Leistungsfähigkeit des
Immunsystems unter Anwendung von Propolisäthanolextrakt (EEP), Esberitox $\mathrm{N}$ und eines Calcium-magnesium-Präparates (Dolomit). Heilkunst 102, 249-255, Apic Abstr (1991) 42, 345

Scheller S, Wilczok T, Imielski S, Krol W, Gabrys J, Shani J (1990) Free radical scavenging by ethanol extract of propolis. Int J Radiat Biol 57, 461-465

Schmalle HW, Jarchow OH, Hausen BM, Schulz KH (1986) Aspects of relationships between chemical structure and sensitizing potency of flavonoids and related compounds. In: Plant Flavonoids in Biology and Medicine (V Cody, E Middleton, JB Harborne, eds), Academic Press, New York, USA, 387 390

Seifert M, Haslinger E (1989) Über die Inhaltsstoffe der Propolis. I. Liebigs Ann Chem 1123-1126

Seifert M, Haslinger E (1991) Über die Inhaltsstoffe der Propolis II. Liebigs Ann Chem 181-203

Serkedjieva J, Manolova N, Bankova V (1992) Antiinfluenza virus effect of some propolis constituents and their analogues (esters of substituted cinnamic acids). J Nat Prod 55, 294-297

Soboleva VA, Kholupyak IY, Kabachnyi GI, Vysochanskaya N, Rogozhin BA (1990) Comparison of the antibacterial and antiinflammatory activities of soft dosage forms with different bases. Farm Zh (Kiev) 5 , 68-69 (in Ukranian)

Stark JA, Glinski Z (1993) El efecto antibacteriano del propóleos. Proc 33rd Int Congr Apiculture, Beijing, China, Apimondia, Bucharest, Romania,142

Stojko A, Scheller S, Szwarnowiecka I, Tustanowski J, Ostach H, Obuszko Z (1978) Biological properties and clinical application of propolis VIII. ArzneimForsch Drug Res 28, 35-37

Stojko R, Stojko A (1993) Uso de preparados apiterapéuticos en la ginecología, Proc 33rd int Congr Apiculture Beijing, China, Apimondia, Bucharest, Romania, 142-143

Strehl E, Volpert R, Elstner EF (1994) Biochemical activities of propolis extracts. III. Inhibition of dihydrofolate reductase. Z Naturforsch 49C, 39-43

Tomás-Barberán FA, García-Viguera C, Vit-Olivier P, Ferreres F, Tomás-Lorente $F$ (1993) Phytochemical evidence for the botanical origin of tropical propolis from Venezuela. Phytochemistry, 34, 191-196

Torres D, Hollands I, Palacios E (1990) Efecto de un extracto alcohólico de propóleos sobre el crescimiento de Giardia lamblia in vitro. Rev Cubana Cienc Vet 21, 15-19

Tosti A, Caponeri GM, Bardazzi F, Melino M, Veronesi $S$ (1985) Propolis contact dermatitis. Contact Dermatitis 12, 227-228

Tóth G (1985) Propolis: medicine or fraud? Am Bee J 125, 337-338

Tóth L, Pápay V (1987) Propolis and its medicinal properties. Egész Munka 34, 325-329 (in Hungarian) 
Trevisan G, Kokelj F (1987) Contact dermatitis from propolis: role of gastrointestinal absorption. Contact Dermatitis 16, 48-49

Tsuchiya $Y$, Shimizu M, Hiyama $Y$ et al (1985) Antiviral activity of natural occurring flavonoids in vitro. Chem Pharm Bull 33, 3881-3886

Tushevskii VF, Porokhnyak LA, Tikhonov Al, Budnikova TM (1991) Morphological aspects of the hepatoprotective effect of propolis tablets. Farmatsev Z5, 7071 (in Ukranian)

Vachy R, Amoros M, Sauvager F (1990) Synergistic virucidal composition containing a phenol compound and propolis useful against lipidic capsid viruses, especially herpes viruses. Fr Patent 90/3, 093, 29 pp

Valdés G, Rojas NM, Morales C (1987) Ensayo preliminar de la acción antifúngica de extractos de propóleo sobre Candida albicans. Cienc Tec Agric, Apicultura 3, 41-49

Valdez Gonzales G, Hernandez NMR, Vera CM (1985) Estudio comparativo de la acción antimicrobiana del propóleos con antibióticos y desinfectantes convencionales. Cienc Tec Agric, Apicultura 1, 23-36

Vanden Berghe DA, Vlietinck AJ, Van Hoof L (1986) Plant products as potential antiviral agents. Bull inst Pasteur 84, 101-147

Vanhaelen M, Vanhaelen-Fastré R (1979a) Propolis I. Origine, micrographie, composition chimique et activité thèrapeutique. J Pharm Belg 34, 253-259

Vanhaelen M, Vanhaelen-Fastré R (1979b) Propolis II. Identification par chromatographies haute-performance (liquide, gas-liquide et sur couches minces) des constituants. Bioautographie des chromatogrammes des composés antibactériens. $J$ Pharm Belg 34, 317-328

Vanhaelen M, Vanhaelen-Fastré R (1980) High-performance liquid, gas-liquid and thin-layer chromatography of naturally occurring flavonoids, phenolic and related compounds. J Chromatogr 187, 255-260

Ventura Coll F, Bonvehi JS, Jordá RE (1993) Propriedades fisico-químicas, composicion y actividades bacteriostáticas de los propóleos producidos en China en el ambito dietético. Proc 33rd int Congr Apiculture Beijing, China, Apimondia, Bucharest, Romania, 142

Villanueva VR, Bogdanovsky D, Barbier M, Gonnet M, Lavie P (1964) Sur l'isolement et l'identification de la 3,5,7-trihydroxy flavone (galangine) a partir de la propolis. Ann Inst Pasteur 106, 292-302

Villanueva VR, Barbier M, Gonnet M, Lavie P (1970) Les flavonoïdes de la propolis : isolement d'une nou- velle substance bactériostatique : la pinocembrine[dihydroxy-5,7 flavanone]. Ann Inst Pasteur 118, 84-87

Volpert R, Elstner EF (1993a) Biochemical activities of propolis extracts. I. Standardization and antioxidative properties of aqueous derivatives. $Z$ Naturforsch $48 \mathrm{C}, 851-857$

Volpert R, Elstner EF (1993b) Biochemical activities of propolis extracts. II. Photodynamic activities. Z Naturforsch $48 \mathrm{C}, 858-862$

Vrijen R, Everaet L, Boeye A (1988) Antiviral activity of flavones and potentiation by ascorbate. $J$ Gen Virol $69,1749-1753$

Walker P, Crane E (1987) Constituents of propolis. Apidologie $18,327-334$

Wang XZ, Tang JX, Li SY (1993) Valuación del efecto curativo de la tintura de propóleos en periodontitis y pericoronitis activas. Proc XXXIII Int Congr Apiculture Beijing, China, Apimondia, Bucharest, Romania, 145

Wanscher B (1976) Contact dermatitis from propolis. $\mathrm{Br}$ J Dermato/ 94, 451-455

Warakomska Z, Maciejewicz W (1992) Microscopic analysis of propolis from Polish regions. Apidologie 23, 277-283

Wleklik M, Luczak M, Panasiak W, Kobus M, LammerZarawska $E$ (1988) Structural basis for antiviral activity of flavonoids-naturally occurring compounds. Antimicrob Agents Chemother 32, 522-525

Woisky RG, Giesbretch A, Salatino A (1994) Antibacterial activity of a formulation prepared with propolis from A mellifera L. Proc IV Iberolatinamerican Meeting Apic, Ministerio de Agricultura, Ganaderia y Recursos Renovables, Rio Cuarto, Argentina, 213216 (in Portuguese)

Yanishlieva N, Marinova E (1986) Application of a new method registering propolis components with antioxidative effects. Khranitelnopr Nauka 2, 45-50 (in Bulgarian), Apic Abstr (1990) 41, 650

Young $E$ (1987) Sensitivity to propolis. Contact Dermatitis $16,49-50$

Zawadzki J, Scheller S (1973) Tests on propolis in the treatment of inflammation of the vagina and cervix. In: Rep 1st Int Symp Propolis (J Cizmárik, ed) Bratislava, Czechoslovakia, 70-72 (in Slovak), Apic Abstr (1977) 28, 1381

Zommer-Urbanska S, Gniadowski R, Bojarowicz $\mathrm{H}$, (1987) Working out the technology of propolis unguentum and its application in vaso-motor catarrh treatment. Proc XXXI int Congr Apiculture, Warsaw, Poland, Apimondia, Bucharest, Romania, 488-492 